\title{
HOW DO MIDWIVES IN SLOVENIA VIEW THEIR PROFESSIONAL STATUS?
}

\begin{abstract}
Objective: The aim of the study was to explore Slovenian midwives' views of their professional status. The influence of participants' educational background on their views was also examined, since higher education is related to professionalism.
\end{abstract}

Design: This was a quantitative descriptive survey, using postal data collection. The questionnaire comprised of six elements crucial for professionalism - three elements distinctive of "old" professionalism (power, ethics, specific knowledge) and three characteristics of "new" professionalism (reflective practice, inter-professional collaboration and partnership with users).

Participants: A total of 300 midwives who were registered in a national register of nurses and midwives at the time of the study. The response rate was 50.7\% (152 returned the questionnaire). Participants that were on a probationary period were excluded, leaving 128 questionnaires for analysis (43\%). Some $40.9 \%$ participants had secondary midwifery education, $56.7 \%$ had higher midwifery education and only few $(2.4 \%)$ finished postgraduate education.

Findings: The majority of participants did not consider midwifery to be a specific profession. Midwives with secondary education were more likely to consider practical skills to be important than theoretical midwifery knowledge. In general midwives did not feel enabled to practice autonomously; and this caused them to face ethical dilemmas when aiming to fulfil women's wishes. All participants with midwifery secondary school education thought that obstetrics jeopardizes midwifery scope of practice, but only half of the BSc participants thought this. One fifth of all participants estimated that midwifery is also threatened by nursing. The respondents reported feeling a lack of control over their professional activity and policy making, however the majority of midwives claimed that they were willing to take on more responsibility for independent practice.

Key conclusions: Slovenian midwifery cannot be considered to be a profession yet. It faces several hindrances, due to its historical development.

Implications for practice: In order to develop a specific professional identity for midwives, the content and structure of education should be analysed and changed in order to improve socialisation and professionalism. In clinical settings, the scope of midwifery practice and responsibilities, as defined by EU directives, should be agreed by all professional groups.

Key words: new professionalism, old professionalism, midwifery, Slovenia. 


\section{Introduction}

Midwifery care has been identified as an essential component of high quality maternal and newborn health care systems (Renfrew et al, 2014), yet in some countries the midwife's role is still questioned. The recent Lancet series on midwifery care identified a framework that set out the scope of midwifery care (Renfrew et al, 2014), identified the impact (Homer et al, 2014), and provided a tool for assessment (Van Lerbergh et al, 2014). However, the series recognised that in many countries there is still work to do if midwifery is to be seen as an autonomous profession (Renfrew et al, 2014); with this in mind, this paper explores the issue of midwifery as a profession from the context of the Slovenian health care system.

Professionalism is connected with the quality of services and with a strong morality of the professionals involved (Abbott and Meerabeau, 1998). People trust professionals because of their expert knowledge and faith in their altruism (Schwirian, 1998), and this is especially important when discussing those professionals involved in health care. With public confirmation, based on trust, professionals gain special status in society, and this provides them with autonomy and respect (Freidson, 1988). Professionalism is attractive to occupational groups since it provides them with this special status, but it is also attractive to service users, because it increases the service quality (Fournier, 1999). Interpretation of professionalism encompasses many and varied aspects. Besides being based on individual characteristics and values, it is largely defined also by context (such as organisational support, workplace, expectations of others, and the specifics of the service users) (Health and care professions council, 2014).

\section{Professionalisation}

Professionalisation, is a collective strategy used by an occupational group to gain the status of a profession (Larson, 1977; Turner, 1995). Approaches to defining an occupational group as a profession vary (Adams, 2003). The most well-known is the trait approach, which lists the characteristics that an occupational group needs to attain in order to gain the status of a 'profession'. The most commonly quoted attributes of a profession were summarized by Turner (1995) as:

- expert esoteric body of knowledge, specific for the professional group;

- autonomy that sets the grounds for jurisdiction on a certain field of practice and imparts to professionals social power;

- $\quad$ and ethical considerations.

These elements are defined as elements of 'old professionalism', since they describe the characteristics of traditional professions (medicine, law and theology). Some claim that these professions gained their status in different social conditions (Leicht and Fennell, 2001) and as a result the defining elements are inadequate for current occupational groups that would like to become professions today. According to some authors (Evetts, 2010; Snoek, 2010; Davies, 1996) the situation in post-modern society is different; authority and hierarchy of traditional professions are no longer appropriate. New characteristics of professions have emerged, such as:

- inter-professional collaboration;

- partnership with users;

- $\quad$ and reflective practice.

These characteristics bring about the so called 'new professionalism' (Davies, 1998). 
These six elements of professionalism, three old and three new, were the theoretical basis for the study performed and described below.

\section{Knowledge}

The basic characteristic of a profession is a highly specialised abstract knowledge (Freidson, 2001) that has to be gained through a university education (Abbot, 1988; Evetts, 2003). The activity of professionals is usually not manual; but when it is, the professional is usually highly responsible and deals with patients' bodies, as in the case of medicine (MacDonald, 1995). Theoretical knowledge is more highly valued (Freidson, 2001). This theoretical knowledge needs to be specific - only professionals from certain groups can solve users' problems; and as a result professions are important for society (Leicht and Fennell, 2001). Because this knowledge defines the profession, members of the profession are proud of it and develop it further within the professional group.

\section{Ethics}

Every profession needs to develop a professional code of conduct to reassure society that they are behaving in a moral manner, since professions serve to provide for the public well-being. However, the existence of a professional code alone is not a satisfactory assurance; the ideology behind the code must also be instilled in the minds of professionals (Freidson, 2001). Professional associations play a major role in the evaluation of their members' work and sanction members for inappropriate acts (Turner, 1995). The public trusts professionals and grants them respect (Evetts, 2006) and this gives them jurisdiction over a certain scope of practice.

\section{Autonomy}

Professionals work independently in their field of work and need specific competencies in order to practise (Fourner, 1999). They take responsibility for the outcomes of this practice. Professional associations supervise them (Freidson, 2001), because only members of a professional group are capable of verifying the appropriateness of another individual's professional work. Professionals have a strong affiliation to their profession (Rainey, 2005) and internalise professional values (Gabe at al., 2004). Society trusts the professional group (Flemming, 1998) and the professional group is also appreciated by other professionals.

\section{Inter-professional collaboration}

In order to collaborate inter-professionally, professional groups need to be mutually respectful. The collaboration is based on the feeling of equality (Crozier, 2003); if one profession feels threatened by another, the opportunity to collaborate is weaker (Hartley, 2002). Good cooperation among professionals improves their satisfaction at work (Keleher, 1998) and empowered professionals more easily leave control to the users (Halliday, 2002).

\section{Partnership with users}

Only active users, that have a feeling of control, can establish partnerships with professionals. Informed decisions are therefore crucial in order to gain an equal position within a relationship (Richards, 1982; Calnan and Rowe, 2008). However in order to leave control to the user, the professional has to be empowered and autonomous in professional decisions (Rodwell, 1996). 


\section{Reflective practice}

The users' estimation of professional work is important in the partnership; however the professional's actions must also be self-evaluated through the process of reflection (Plack and Greenberg, 2005) and in a group that offers peer-support. As a consequence, Epstein and Hundert (2002) claim that reflective practice is crucial for professional development.

This paper describes a study that aimed to apply all of these elements of professionalisation to Slovenian midwifery. Since midwifery has a different historical development to that of medicine (Witz, 1992; Symonds and Hunt, 1996; Lupton, 2006) it was anticipated that midwifery would identify more strongly with the elements of 'new' professionalism.

\section{Slovenian midwifery}

It is worth first considering the specific situation of midwifery within the Slovenian context; a situation that is common to many East European countries, because they underwent a similar historical development (Stromerova, 2012; Fleming and Holmes, 2005).

Slovenia is a small country, with approximately 21,000 births per year (Euro-Peristat, 2010). It has a low neonatal mortality rate; in 2010 the perinatal mortality rate was 2.71 per 1000 live births (RS UKOM, 2012). In the years from 2006-2010 the maternal mortality ratio was 14.6 per100.000 live births (MFZFD, 2015). Despite having a caesarean section rate still under $20 \%$ in 2010 (Euro-Peristat, 2010), the country has seen a rise in this obstetric intervention in the past few years.

In Slovenia midwifery still struggles to attain recognition as an autonomous profession that should, according to the International Confederation of Midwives (2011), independently determine and control the standards for education, regulation and practice.

Despite a strong tradition of midwifery, different historical turning points have meant that midwives in Slovenia are not autonomous (Mivšek, 2015). After the Second World War birth in Slovenia was redirected from the home to hospitals (Rožman, 2004) that were under the control of the medical profession and where the independent role of the midwife was slowly converted into the role of an obstetric nurse. In 1980 the midwifery (secondary) school that had educated midwives since 1753 was closed. The result was a shortage of midwives within a few years of the closure. Midwives were therefore redirected to work in delivery rooms. Antenatal care was taken over by gynaecologists and obstetricians, postnatal care by nurses (Mivšek, 2015). This fragmented system of maternal and newborn care does not offer the interdisciplinary and integrated approach to skilled care recommended by Renfrew et al (2014).

Midwives who finished secondary education are still present in the delivery rooms in Slovenia. Their scope of practice and responsibilities are the same as the competencies of BSc midwives, who graduated from 2000 on.

Midwifery education was re-established in 1996 on a diploma (BSc) level, with the first midwives graduating in 2000. These midwives finished the three year programme and had to do a nine month probation period (a period working under supervision). During this probationary period the midwives worked with a mentor. They were not yet autonomous and could not take full responsibility for their professional activity. After 9 months of probation 
they sat a national exam at the Ministry of Health. If they passed this practical and theoretical exam, they could work independently. In 2004, when Slovenia joined the EU, the midwifery programme was implemented according to the EU directives (the practice of a probationary period was included in the programme; however it remained a 3-year programme). New contents were added on a theoretical level (biochemistry, biophysics, embryology etc.) and also practical training in simulation rooms (suturing of the perineum, examination of the newborn, managing breech deliveries, management of healthy pregnant and postpartum women etc.), however students rarely have an opportunity to practice these skills in clinical settings (there they are still performed by doctors or nurses).

The probationary period was abolished in December 2008, when the first midwives from the EU implemented study programme graduated. With this programme graduates gained a licence with their diploma. However at the time of the survey, there were still some individuals in the clinical settings that needed to finish their probationary period in order to be considered competent to practice.

Midwifery education was always direct entry; however a lot of obstetricians and nurses teach in the programme, because the midwifery profession has only a few academics. Midwifery education is also not yet established at masters or doctoral level.

As previously stated, graduates are usually employed in the delivery rooms, because antenatal and postnatal care is still controlled by other professions. Today, midwives still work only in the institutions of the national health care system, where midwifery is usually subordinate to medicine (Mivšek, 2015). Looking from this perspective it might be expected that midwives in the study would report a low level of perceived professionalism, but since higher education is supposed to enhance professionalism, we anticipated that the answers from participants with BSc level or postgraduate education might differ.

Midwives in Slovenia still lack national midwifery legislation to define their scope of practice. A joint association of nurses and midwives governs midwifery practice, but midwives are in the minority. The register of professionals was established in 2007 by the National Nursing and Midwifery Association. Prior to 2007 midwives (and nurses) were not registered. However in 2010 the Ministry of Health did not renew the jurisdiction of licencing and registering, and the Nursing and Midwifery Association lost the competency to manage the register. As a result the register of professionals is still not complete.

\section{Aims and objectives}

The aim of the study was to determine how Slovenian midwives view the professional status of Slovenian midwifery, according to the elements of 'old' and 'new' professionalism. The research questions which led our study were:

- Which elements of professionalism are present in Slovenian midwifery?

- Is perception of the elements of professionalism different according to the level of education of the midwives?

\section{Methods}

A deductive approach was adopted, involving a descriptive method in order to gain insight into the current situation regarding professionalism in Slovenian midwifery. 


\section{Research design}

This was a survey that used a postal questionnaire sent to Slovenian midwives working in practice and education.

\section{Research tool}

We tried to attain better reliability and validity of the research tool by using questions from an existing research tool (Hampton and Hampton, 2000, 2004). We used these questions to test the elements of 'old' professionalism and translated them into Slovenian. Questions for testing the elements of 'new' professionalism were derived from a literature review. Terminology within the questionnaire was adapted for Slovenian circumstances (for example the term "nurse-midwives" was changed to "midwives"). The questionnaire was discussed with the $\mathrm{PhD}$ supervisors who advised on the development of the research tool and in the survey process. Expert review of the research tool is said to improve content validity (Polit et al., 2001). It was tested with six midwives who had different educational backgrounds to assess comprehension of the questions. No ambiguity was expressed; therefore no changes were made.

The final version of the questionnaire was composed of two main parts. In the first part, demographic data were collected, while in the second part we gathered midwives' opinions regarding midwifery professionalism. On the basis of the six elements of professionalism (three elements of 'old' and three elements of 'new'), six matrices of statements were formed and agreement measured with a 4-point Likert scale that did not allow a neutral response; participants had to opt for agreement or disagreement. This encourages the participants, called floaters, who always opt for the neutral option where it is given (Neuman, 2006).

\section{Sampling and data collection}

When the study was performed, the national register of nurses and midwives was not introduced completely; only 300 midwives were registered at the time. Challenges in maintaining the register continue and therefore it is still practically impossible to estimate the population of Slovenian midwives. All registered midwives at the time of the survey, were selected as participants. According to the most optimistic estimations regarding the number of midwives in Slovenia (654 members of midwifery as stated by the World Health Organization (2006)) that meant $45.9 \%$ of the population.

Data were collected by postal questionnaires sent in 2008 and 2009. Participants returned their responses in the envelopes provided. During the data collection phase, one written reminder was sent to all participants. The response rate was $50.7 \%(\mathrm{~N}=152)$. Participants that were on a probationary period were excluded leaving 128 questionnaires for the analysis $(43 \%)$. These exclusions were the individuals described above who still had to finish their probationary period in order to be competent to practice.

\section{Ethics}

The researcher followed the principles of research ethics, to maintain the integrity of the participants. The addresses of the participants were obtained from the National Nursing and Midwifery Association that held the register of midwives in Slovenia at that time. In order to gain the association's consent, the study had to be presented in their honorary court of arbitration. Midwives were contacted through the association and were informed that their 
participation was voluntary and anonymity would be assured. Lack of participant identifiers on the questionnaires, in order to assure the anonymity, meant that reminders had to be sent to all participants.

\section{Analysis}

Data were processed with the SPSS 18 programme. In the process of the analysis first the basic descriptive statistics were calculated. In the second step crosstabs were used to identify differences in the opinions of the participants regarding the elements of professionalism, according to their level of education (chi square test).

Data were divided according to the professionalisation elements of 'new' and 'old' professionalism. We expected differences in opinions with regard to the level of the participant's education, since some researchers claim that a higher level of education is connected with a higher level of professionalism (Gurney et al., 1997). Therefore we divided the group into participants who had finished secondary midwifery education (before 1982) and BSc participants, who finished BSc or postgraduate education (after 1996).

\section{Findings}

The results presented reflect participants' views regarding the professionalism of Slovenian midwifery.

\section{Demographic data}

The final response rate was $43 \%$. Almost all participants $(98.4 \%)$ were female (only two participants were male). With regard to age: $46.7 \%$ participants were more than 40 years old, $53.3 \%$ aged from $20-40$ years.

Approximately half of the group (40.9\%) had secondary midwifery education, $57.5 \%$ of participants had finished the undergraduate programme and two participants had finished postgraduate education.

The maternity hospital was the most common place of employment $(64.1 \%)$, with most participants working as a midwife in the delivery suite (53.7\%). The next most often quoted place of employment was the community (12.5\%). Two participants were employed in the midwifery school and four of them in private practice (but not as independent midwives).

Approximately one third (38.7\%) of midwives had less than 5 years of working experience, $29 \%$ more than 25 years. Few participants occupied managerial positions (15.4\%).

\section{Data regarding professionalism}

The results regarding statements about 'old' elements of professionalism are shown in Table 1. More than half of the midwives $(63 \%)$ thought practical skills were more important for the midwifery profession than theoretical knowledge. Almost half of them (41\%) thought that a diploma was not necessary in order to practice midwifery. The only statistically significant difference between the two educational groups was seen in answers regarding the necessity of having at least $(\mathrm{BSc})$ diploma degree to start practicing midwifery $\left(\chi^{2}=17,211, \mathrm{p}<0,001\right)$. 
A lot $(59 \%)$ of participants were not in favour of direct entry midwifery education, while slightly less (39\%) thought midwifery was a not specific profession, but a branch of nursing.

All participants (100\%) claimed that they practiced ethically, but when it came to evaluating their colleagues' ethics they were more critical (90\%).

Almost all (98\%) participants thought that midwifery is important for society and felt proud to be midwives, however $34 \%$ felt that society did not appreciate midwifery. In contrast, they did feel appreciated by other health professions, who often seek their professional advice. Still a lot of participants did not feel that they had professional autonomy and therefore did not feel competent to manage physiological pregnancy, birth and the postnatal period. The majority (78\%) were willing to take on more professional responsibility in order to practice more independently.

Professional associations have a strong role in establishing the autonomy of the profession and $67 \%$ of participants thought that the Slovenian Midwifery Association was not proactive enough in promoting midwifery.

Participants' opinions regarding the elements of new professionalism are presented in Table 2. Almost all (90\%) participants stated that they practice informed decision making and $74 \%$ that they prioritise women's wishes, however almost three quarters of them see their lack of independence as an obstacle to fulfilling women's wishes. In contrast, a fifth of participants admitted that they felt a lack of control when practising partnership with women, which could be understood as not wanting to share decision making with women. The strong agreement with the statement "I usually quickly recognise the problems of the user and choose the best solution to solve them" can also be seen as problematic when discussing users' active involvement in midwifery care.

Participants also felt that other health professionals could threaten their scope of practice. More than a quarter of participants felt that nurses (26\%) jeopardise midwifery practice, while nearly half felt that doctors (48\%) jeopardise midwifery practice. Despite these feelings, more than $80 \%$ of participants reported that they are still professionally respected by both groups.

The fact that only $32 \%$ of participants agreed with the statement "where I work we regularly discuss our professional work" confirms that midwives themselves do not have strong professional supervision networks. Low agreement with the statement "I always verify the quality of my work with superiors", also acknowledges that. The participants most often assess the quality of their work with users, but less often with colleagues or supervisors.

\section{Discussion}

Special theoretical knowledge is said to be the base of a profession (Symonds and Hunt, 1996). Midwifery is associated with more efficient use of resources and improved outcomes of care when provided by midwives who are educated, trained, licensed, and regulated, and there is evidence that midwives are most effective when integrated into the health system, (Renfrew et al., 2014).

Experts claim that midwifery education must be raised to the academic level of MSc or PhD (Pehlke-Milde et al., 2006). An association between higher degrees and a rise in 
professionalism was confirmed in this study and mirrors the findings of Hampton and Hampton (2000). We found that Slovenian midwives, especially those with less than a diploma (BSc) level of education, think that practical skills are more important than theory and that diploma level education is not necessary to practise midwifery. Pahor and Domajnko (2010) state that there is an anti-intellectual stream of individuals in Slovenian nursing and midwifery. This group have developed a specific subculture of low-educated members who praise practical skills and undervalue education. This perception might derive from the fact that midwives in Slovenia were historically the most autonomous (in the time of community midwives who were not formally educated) and their practical expertise was the key to their autonomy. However, some claim that this practical (or traditional) knowledge that used to lead midwifery to the legitimate autonomy is in opposition to modern discourses of science and theory (Boje, 1995). Lively debate regarding the value of degrees in nursing and midwifery is still present in a number of countries, other than Slovenia (Spencer, 2006; The Guardian, 2015). Kirkham (1998) claims that midwifery should combine all types of knowing, while others suggest a more pure scientific way (Pehlke-Milde et al., 2006; Tierney, 1997; Treacy and Hyde, 1999).

In Slovenia midwifery education is direct entry, which is argued to provide better outcomes and a stronger professional identity (Leap, 2000), and this enables a better understanding of professional roles. The outcome of direct entry programmes is said to enhance a midwifery philosophy that promotes physiology (Lay, 2000; Kornelsen and Carty, 2004). Midwives in the study by Hampton and Hampton (2000) strongly supported the direct entry midwifery programme. In our study the majority of the participants did not see midwifery as a specific expertise, despite the fact that midwifery was always a special and separate educational course; however they were proud of their profession. The main reason for this is likely to be the current circumstances of midwifery in Slovenia. At present Slovenian midwives do not practice all midwifery activities, as defined within the scope of practice for midwives by the EU directives, and the borders between nursing, midwifery and obstetrics are often blurred. This has also been found by studies from other countries with similar situations to Slovenia, due to similar historical backgrounds (Hresanova, 2007).

Midwifery care affects quality of care for pregnant families, and poor quality care is not just about the absence of services. There is global concern about the overuse of interventions and increasingly medicalised care (Renfrew et al., 2014). Midwifery philosophy promotes the physiology of pregnancy, birth and postpartum. However Slovenian women still traditionally seek care from a gynaecologist-obstetrician, when they conceive. Only 30\% of women who participated in a national study of birth in Slovenia (Mivšek, 2007) realised benefits of receiving antenatal care from midwives.

Disappointment over the current situation can also be seen in our study, and in particular in participants' answers regarding midwives' reputation in society. Almost all of the participants agreed that midwifery is important for society, which is an important attribute of professionalism (Hampton and Hampton, 2000), but more than a third thought that society does not appreciate their work. These results were contrast with the findings of Hampton and Hampton (2000), where satisfaction with the work and autonomous practice were strongly connected; participants practised autonomously and had the feeling that their role was well recognised and respected in society. It is likely that the Slovenian public is not fully aware of the midwifery profession - further studies would be necessary to gauge public opinion and see if the public can differentiate between nurses and midwives. There is some evidence that 
users in other countries often mistake midwives for nurses (Hresanova, 2007), since their autonomy and roles in the hospital are similar.

All participants claimed to practice ethically but often felt that they could not fulfil users' wishes (and might therefore encounter ethical dilemmas) due to a lack of autonomy. Autonomy is one of the crucial issues in professionalism (Freidson, 1988; Leicht and Fennell, 2001), however only $40 \%$ of participants in our study felt that they could practice autonomously. Some even estimated that they were not competent or able to carry out the basic midwifery competences such as caring for a healthy pregnant, labouring or postpartum woman and a baby by themselves. Since autonomy is closely connected with responsibility, it is surprising to find that one fifth of the participants were happy with the situation and were not willing to take over more professional responsibility. Accepting responsibility is key to becoming an independent profession (Fleming, 1998; Symon, 1996). However, midwives who work in hospitals are often subordinated to medicine or/and nursing (Fleming, 1998), a process that is sometimes promoted even by the midwives themselves (Bryar, 1995). As a result, some claim that it would be impossible for midwifery to gain complete independence within these institutions (Baly, 1995; Kirkham, 1998).

An additional factor that may inhibit the autonomy of midwives in Slovenia is the undefined scope of practice, roles and responsibilities of midwives. Professionalisation is a political action of a profession and should be driven by a professional association (Abbott, 1988), but almost three quarters of participants thought that the midwifery section within the Slovenian Nursing and Midwifery Association does not provide enough support for their profession. This result is diametrically opposite to the findings of the study by Hampton and Hampton (2000). The passive role of professional organisations can also be a hindrance in asserting midwifery autonomy. One of the explanations is that midwifery in Slovenia has a joint association with nursing (where midwives are in the minority and have little political impact). In certain circumstances this can lead to conflict between the two professions (for example if midwives want to gain back their scope of practice in relation to postpartum care, which is currently done by nurses).

If midwives feel that they lack power then it is less likely that they will be able to empower women (Pahor, 2009); however women wish to be more active and to have more control over what is happening to them and their babies (Cutts et al., 2003) during pregnancy, birth and postpartum. In low-income and middle-income countries, users are becoming more demanding; they want high-quality and safe care during pregnancy and childbirth (Hoope Bender et al., 2014). Women want health professionals who have clinical knowledge and skills and are at the same time empathic, and possess interpersonal and cultural competence (Renfrew et al., 2014). Informed decision-making is an extremely important element in the context of partnership with women (Lupton, 2006). Participants' responses regarding their cooperation with users in our study are controversial. On the one hand they know that women want to be active in the management of their pregnancy and labour and they feel that women should be able to decide the care they receive, but one quarter of participants felt threatened by the loss of control involved in shared decision-making (diploma level midwives more often than midwives with secondary education). There was a high level of agreement with the statement "I often see the problem of a woman and find the best solution to solve it" which may suggest that all previous answers of participants were socially-desired. The Slovenian national study of birth (Mivšek, 2007) that explored women's views and satisfaction with care in pregnancy, birth and postpartum, showed that women often do not have the opportunity to make decisions regarding procedures. This may be indicative of the reluctance of midwives to 
share decision-making with women. Midwives should become aware that users play a major role in the professionalisation process; thus society defines the level of autonomy of the profession (Freidson, 1988). The findings in our study regarding reflective practice, which indicate that midwives most often verify the quality of their work with users, might demonstrate their growing awareness of the importance of users' satisfaction.

Besides users' views, acknowledgement from other professions is also an important element of professionalism (Adams, 2003). Midwives in the study estimated that the professional respect for midwifery demonstrated by nurses and obstetricians was good and that they felt that cooperation in the health care team where they worked was solid. This is also very important from the users' point of view, since good relationships set the working atmosphere and can consequently also affect women's satisfaction with care (Pahor, 2009). Hoope Bender et al. (2014) write that to ensure expectations of users regarding the quality of care, competencies of all health practitioners that work with pregnant, labouring and postpartum women should be brought together into an interprofessional team. Equality among cooperative professions is crucial for collaboration; differences in power negatively affect these relationships (San Martin-Rodriguez et al., 2005).

Some participants in our study expressed feelings of threat. Since the boundaries of subordinated professions are often challenged (Leicht and Fennel, 2001), they usually perceive more threat from other professional groups (Darling and Ogg, 1984; Hartley, 2002). It was obvious that Slovenian midwives felt that midwifery is threatened by obstetrics, probably due to the historical subordination of nursing and midwifery by medicine and the fact that very hierarchical relationships between these professions still remain in East European countries (Stromerova, 2012). Some midwives even felt that midwifery is threatened by nursing, which may be due to the fact that the scope of practice between the professions is not clearly defined and nurses are the profession that usually occupies management positions in maternity hospitals (Mivšek and Beričič, 2011). This perception of threat could be a reason why midwives so rarely verified the quality of their work with their superiors (usually nurses) and why they felt that midwifery practice was being evaluated by other professions. Another reason could be that Slovenian policy still considers doctors to be responsible for physiological pregnancy, birth and postpartum. Midwives should take on the responsibility for the care of women during normal pregnancy, birth and postnatal period. However, they should also be ready to cooperate in interdisciplinary teams that can offer specialised care when needed (Sakala and Newburn, 2014). Outcomes are optimal when care is led by midwives who are educated, licensed, regulated, and integrated in the health system. Renfrew et al. (2014) found that when obstetricians care for women during pregnancy, childbirth and postpartum mortality and morbidity rates improve, however if there are no midwives in the health system, that might also reduce quality and increase cost.

In summary, it could be argued that Slovenian midwifery has a strong element of professionalism in terms of ethics. In the case of knowledge, the only statistically significant difference was between undergraduate and secondary school participants, confirming the findings of previous studies that suggest raising the educational level results in a rise in the level of professionalism. The results on collaboration with users remain ambiguous. Weak elements of Slovenian midwifery professionalism are autonomous practice and professional confidence (demonstrated by participants reporting a highly perceived threat from related professions). 
There are certain limitations of the described study that could potentially affect the quality of the results. One of the major restraints is the identification of the sample; because of the lack of a formal midwifery register there are no exact data on how many midwives in the population have secondary education and how many have diploma level education and it is hard to estimate therefore whether we used a representative sample. However, professionalism can be understood to be a subjective characteristic of the individual professional that influences the general picture of professionalism of the group (Hampton and Hampton, 2000); so it could be claimed that the answers of participants that were a part of our sample might reflect the opinion of the whole population of Slovenian midwives. Although care was taken to use existing, validated questions within the tool, translation was limited by resources. One of the improvements of the study could be a double blind translation of the questionnaire, as suggested by Hampton and Hampton (2000). Finally, the study explored the issue of professionalism from a quantitative perspective. Challenges to midwifery autonomy could be investigated in more specific detail by using qualitative approaches such as focus group interviews.

\section{Conclusion}

Slovenian midwifery cannot be determined to be a profession at this point. The crucial recommendation for practice that derives from the findings of the study is that the scope of autonomous midwifery practice and responsibilities have to be re-defined. The role of the midwife needs to be expanded to at least include the scope of practice set by the EU directives. Currently Slovenian midwifery is mainly limited to intrapartum care, where it confronts boundaries imposed by obstetrics. As Horton and Astudillo (2014, p.1075) wrote: "A frequent view is that midwifery is about assisting childbirth. It is, but it is also much more than that." The midwifery model of care has been shown to be effective in terms of improved health outcomes and cost, however education of health-care professionals and efficient regulation of practice are important prerequisites. In addition, it is important to create cooperation between care providers and clients (Hoope Bender et al., 2014).

Midwifery professionalisation has to be driven by midwives themselves, as successfully proven by some countries (Kornelsen and Carty, 2004). 'Professionalisation from within', where the initiative arises from the professional group itself (McClelland, 1990), results in stronger professional identity and affiliation to the profession (Evetts, 2003). However, enforcement of an occupation as a profession has to be confirmed also by society and related professions, therefore the scope of midwifery practice should be defined in agreement with obstetricians and nurses. Good collaboration among health professionals can improve the quality of care for clients (Shamian, 2014), however collaboration is always considered as a partnership of equals (Hartley, 2002). As seen in our study the Slovenian midwifery profession feels that its values are threatened by other professions in the health care system. In order to be well represented in the negotiations for autonomous jurisdiction, midwives might benefit by having their own professional association, which would be more politically active and promote the profession in public.

Midwifery education in Slovenia does not currently achieve a strong professional identity for midwives, despite the long tradition of a direct entry approach. It might be that students spend too much time in medicalised practice settings, where the role of the midwife is not promoted enough. Stone and Arulkumaran (2014) write that in some countries teachers do not work in clinical settings anymore and that therefore the hidden curriculum of tradition prevails; 
however this is not the case in Slovenia. It might be that the philosophy of midwifery care cannot be passed over to graduates, since only a few subjects in the programme are taught by midwives, because of a lack of midwifery teachers. Further research is needed to identify the hindrances in this regard.

This is the first study on professionalism of midwifery in Slovenia that gives an insight to the opinions of Slovenian midwives. The awareness of these attitudes is crucial in order to make strategies regarding the future professional development of midwifery practice, education and policy. 


\section{References}

Abbott, A., 1988. The system of the professions. University of Chicago press, London.

Abbott, P., Meerabeau, L., 1998. Professionals, professionalization and the caring professions. In: Abbott, P., Meerabeau, L., eds. The sociology of the caring professions. 2nd ed. Routledge, Abingdon.

Adams, T.L., 2003. Professionalization, gender and female-dominated professions: dental hygiene in Ontario. The Canadian review of sociology and anthropology 40(3), 267-289.

Baly, M., ed., 1995. Nursing and social change. 3rd ed. Routledge, London.

Boje, D.M., 1995. Stories of the story-telling organisation: a postmodern analysis of Disney as 'Tamara-land'. Academy of Management Journal 38(4), 997-1036.

Bryar, R.M., 1995. Theory for midwifery practice. Macmillan press, Basingstoke.

Calnan, M., Rowe, R., 2008. Trust relations and changing professional governance: theoretical challenges. In: Kuhlmann, E., Saks, M., eds. Rethinking professional governance: international directions in healthcare. Policy Press, Bristol.

Crozier, K., 2003. Interprofessional education in maternity care: shared learning for women-centred care. International journal of sociology and social policy 23(4/5), 123-138.

Cutts, D., David, P.M., McIntyre, M., Seibold, C., Hopkins, F., Miller, M., 2003. Werna Naloo-'we us together': the birth of a midwifery education consortium. Journal of advanced nursing 41(2), 179-186.

Darling, L.A., Ogg, L.H., 1984. Basic requirements for initiating an interdisciplinary process. Physiotherapy 64(11), 1648.

Davies, C., 1996. The sociology of professions and the profession of gender. Sociology 30(4), 661-678.

Davies, C., 1998. The cloak of professionalism. In: Allott, M., Robb, M., eds. Understanding health and social care. SAGE, London. pp. 190-197.

Domajnko, B., Pahor, M., 2010. Mistrust of academic knowledge among nurses in Slovenia. International nursing review 57(3), 305-311.

Epstein, R.M., Hundert, E.M., 2002. Defining and assessing professional competence. JAMA 287(2), 226-235.

Euro-Peristat, 2010. European Perinatal Health Report - Health and Care of Pregnant Women and babies in 2010. http://www.europeristat.com/images/doc/EPHR2010_w_disclaimer.pdf (5.7.2015)

Evetts, J., 2003. The sociological analysis of professionalism: occupational change in the modern world. International sociology 18(2), 395-414. 
Mivšek P, Pahor M, Hlebec V, Hundley V (2015) How do midwives in Slovenia view their professional status? Midwifery (early online) http://www.sciencedirect.com/science/article/pii/S0266613815002260

Evetts, J., 2006. Trust and professionalism: challenges and occupational changes. Current sociology $54,515-531$.

Evetts, J., 2010. Organizational Professionalism: changes, challenges and opportunities. http://www.irspm2010.com/workshops/papers/12_organizational.pdf (18.2.2015)

Fleming, V.E.M., 1998. Autonomous or automatons? An exploration through history of the concept of autonomy in midwifery in Scotland and New Zealand. Nursing ethics 5(1), 4351 .

Fleming, V., Holmes, A., 2005. Basic nursing and midwifery education programmes in Europe. http://www.euro.who.int/_data/assets/pdf_file/0013/102235/E86582.pdf (29.1.2015)

Fournier, V., 1999. The appeal to professionalism as a disciplinary mechanism. Social review 47(2), 280-307.

Freidson, E., 1988. Profession of medicine: a study of the sociology of applied knowledge. University of Chicago press, Chicago.

Freidson, E., 2001. Professionalism: the third logic. Polity Press, Cambridge.

Gabe, J., Bury, M., Elston, M.A., 2004. Key concepts in medical sociology. Thousand oaks, London.

Gurney, C.A., Mueller, C.W., Price, J.L., 1997. Job satisfaction and organizational attachment of nurses holding doctoral degrees. Nursing Research 46(3), 163-171.

Hampton, D., Hampton, G.M., 2000. Professionalism and the nurse-midwife practitioner: an exploratory study. Journal of the American academy of nurse practitioners 12(6), 218-225.

Hampton, G.M., Hampton, D.L., 2004. Relationship of professionalism, rewards, market orientation and job satisfaction among medical professionals: The case of certified nursemidwives. Journal of business research 57, 1042-1053.

Halliday, S.V., 2002. Barriers to customer-orientation: a case applied and explained. European journal of marketing 36(1/2), 136-158.

Hartley, H., 2002. The system of alignments challenging physician professional dominance: an elaborated theory of countervailing powers. Sociology of health and illness 24(2), 178-207.

Health and Care Professions Council, 2014. Professionalism in healthcare professionals. London: Health and Care Professions Council. http://www.hpcuk.org/assets/documents/10003771Professionalisminhealthcareprofessionals.pdf (3.5.2015)

Homer CSE, Friberg IK, Bastos Dias MA, et al, 2014. The projected effect of scaling up midwifery. Lancet 384(9949), pp. 1146-57.

Hoope Bender, P., de Bernis, L., Campbell, J., Downe, S., Fauveau, V., Fogstad, H., Homer, C.S.E., Powell Kennedy, H., Matthews, Z., McFadden, A., Renfrew, M.J., Van Lerberghe, W., 2014. Improvement of maternal and newborn health through midwifery. 
Lancet 384(9949), pp. 1226-1235.Horton, R., Astudillo, O., 2014. The power of midwifery. The Lancet series 384(9949), p. 1075-1076.

Hresanova, E., 2007. Midwives, women, and the professionalization of midwifery: an ethnographic study of two maternity hospitals in the Czech Republic. Cognition, Brain, Behavior 11(2), 371-397.

ICM, 2011. Midwifery: an autonomous profession. http://www.internationalmidwives.org/assets/uploads/documents/Position\%20Statements\%20 $=$ \%20English/PS2011_011\%20ENG\%20Midwifery\%20an\%20Autonomous\%20Profession.pdf $(15.5 .2015)$

ICM, 2014. Final report of $30^{\text {th }}$ ICM triennial congress, Midwives: Improving Womens Health Globally, Prague, June 2014. http://internationalmidwives.org/what-wedo/regulation/triennial-report.html (4.12.2014)

ICM, 2015. Midwives associatons. http://www.internationalmidwives.org/who-weare/midwives-associations/?stringFilter $=\&$ regionFilter $=6 \&$ countryFilter $=0 \&$ doFilter $=$ Find $(15.5 .2015)$

Keleher, K.C., 1998. Collaborative practice characteristics, barriers, benefits and implications for midwifery. Journal of nurse-midwifery 43(1), 8-11.

Kirkham, M., 1998. Professionalization: dilemmas for midwifery. In: Abbott, P., Meerabeau, L., eds. The sociology of the caring professions. 2nd ed. Routledge, Abingdon.

Kornelsen, J., Carty, E., 2004. Challenges to midwifery integration: interprofessional relationships in British columbia. In: Bourgeault, I.L., Benoit, C., Davis-Floyd, R., eds. Reconceiving midwifery. McGill-Queen's university press, Montreal.

Kornelsen, J., Dahinten, S.V., Carty, E., 2003. On the road to collaboration: nurses and newly regulated midwives in British Columbia, Canada. Journal of midwifery and women's health 48(2), 126-132.

Larson, M.S., 1977. The rise of professionalism: a sociological analysis. University of California press, Berkeley.

Lay, M.M., 2000. The retoric of midwifery: gender, knowledge and power. Rutgers University press, New Brunswick.

Leap, N., 2000. Charting new waters in midwifery education. Annual New South Wales conference Midwifery creating a sea change. Midwives Association, Sydney.

Leicht, K., Fennell, M., Witkowski, K., 1995. The effects of hospital characteristics and radical organizational change on the relative standing of health care professions. Journal of health and social behavior 36, 151-167.

Lupton, D., 2006. Medicine as a culture. 2nd ed. SAGE publications, London:.

MacDonald, K.M., 1995. The sociology of the professions. SAGE publications, London. 
McClelland, C.E., 1990. Escape from freedom? Reflections on German professionalization 1870-1933. In: Torstendahl, R., Burrage, M., eds. The formation of professions: knowledge, state and strategy. SAGE publications, London, pp.97-113.

MFZFD - Mednarodni Forum Znanstvenoraziskovalnih Farmacevtskih Družb, 2015. Poročilo opozarja na umrljivost in obolevnost mater in dojenčkov $\mathrm{v}$ Evropi. http://www.firdpc.com/sl/Aktualno/Porocilo_opozarja_na_umrljivost_in_obolevnost_mater_i n_dojenckov_v_Evropi/ (21.7.2015)

Mivšek, A.P., 2007. Slovenske ženske v pričakovanju: sprijaznjene in pasivne ali aktivne in zadovoljne uporabnice obporodnega zdravstvenega varstva. In: Drglin Z., ed. Rojstna mašinerija: sodobne obporodne vednosti in prakse na Slovenskem, (Knjižnica Annales Majora). Univerza na Primorskem, Znanstveno-raziskovalno središče, Založba Annales; Zgodovinsko društvo za južno Primorsko, Koper. pp. 73-103, 216-217.

Mivšek, A.P., 2015. Meeting the challenges of midwifery education in Slovenia: a historical overview. Essentially MIDIRS 6(4), 19-22.

Mivšek, A.P., Beričič, K., 2011. Zaposlenost in kadrovske potrebe po diplomiranih babicah v Sloveniji. Obzornik zdravstvene nege 45(2), 93-100.

Neuman, W.L., 2006. Social research methods. 6th ed. Qualitative and quantitative aaproaches. Pearson, Allyn and Bacon, Boston.

Pahor, M., 2009. Medpoklicno sodelovanje v zdravstvu: socialna omrežja kot dejavnik varnega in zdravega delovnega okolja. In: Cvahetovi dnevi javnega zdravja. Zbornik prispevkov, september 2009. Medicinska fakulteta; Katedra za javno zdravje, Ljubljana. pp. $148-158$.

Pehlke-Milde, J., Beier, J., zu Sayn-Wittgenstein, F.P.H., Fleming, V., 2006. Vocational analysis of health care professions as a basis for innovative curricular planning. Analysis and prognosis of the development of the professional competencies of midwives - cornerstones of innovative curricula in tertiary education. Nurse education today 26, 183-190.

Plack, M.M., Greenberg, L., 2005. The reflective practitioner: reaching for exellence in practice. Pediatrics 116, 1546-1552.

Polit, D.F., Beck, C.T., Hungler, B.P., 2001. Essentials of nursing research-methods, appraisal and utilization. $5^{\text {th }}$ ed. Lippincot, Philadelphia.

Rainey, K.T., 2005. Approaches to professionalism-a codified body of knowledge. Proceedings IEEE International professional communication conference. IEEE, Minneapolis. pp. 679-683.

Renfrew, M.J., McFadden, A., Bastos, M.H., Campbell, J., Channon, A.A., Cheung, N.F., Audebert Delage Silva, D.R., Downe, S., Powell Kennedy, H., Malata, A., McCormick, F., Wick, L., Declercq E., 2014. Midwifery and quality care: findings from a new evidenceinformed framework for maternal and newborn care. Lancet 384(9949), pp.1129-45.

Richards, M.P.M., 1982. The trouble with choice in childbirth. Birth 9, 253-260. 
Mivšek P, Pahor M, Hlebec V, Hundley V (2015) How do midwives in Slovenia view their professional status? Midwifery (early online) http://www.sciencedirect.com/science/article/pii/S0266613815002260

Rodwell, C.M., 1996. An analysis of the concept of empowerment. Journal of Advanced Nursing 23, 305-313.

Rožman, I., 2004. Peč se je podrla: kultura rojstva na slovenskem podeželju v 20. stoletju. Slovensko etnološko društvo, Ljubljana.

RS UKOM, 2012. Mnenje ministrstva za zdravje o racionalizaciji delovnih mest $\mathrm{v}$ zdravstvu.

Sakala, C, Newburn, M., 2014. Meeting needs of childbearing women and newborn infants through strengthened midwifery. The Lancet series 384(9949), pp. E39-40.

Schwirian, P.M., 1998. Professionalization of nursing: current issues and trends. 3rd ed. Lippincott, Philadelphia.

Shamian, J., 2014. Interprofessional collaboration, the only way to Save Every Woman and Every Child. The Lancet series 384(9949), pp. e41-42.

Snoek, M., 2010. Theories on and concepts of professionalism of teachers and their consequences for the curriculum in teacher education. http://www.kenniscentrumonderwijsopvoeding.hva.nl/content/kenniscentrum/lereneninnovere n/documenten/Theories-on-and-concepts-of-professionalism-and-their-consequences-for-thecurriculum-in-teacher-education.doc (18.9. 2014).

San Martin-Rodriguez, L., Beaulieu, M.D., D'Amour, D., Ferrada-Videla, M., 2005. The determinants of successful collaboration: a review of theoretical and empirical studies. Journal of interprofessional care 19(s.1), 132-147.

Spencer, R.L., 2006. Nurses', midwives' and health visitors' perceptions of the impact of higher education on professional practice. Nurse education today $26,45-53$.

Symon, A., 1996. Midwives and professional status. British journal of midwifery 4(10), 543-550.

Stone, W., Arulkumaran, S., 2014. Health-care professionals in midwifery care. The Lancet series 384(9949), pp. 1169-1170.

Stromerova, Z., 2012. Midwifery in East Europe: challenges and solutions. Midwifery matters 133, 4.

Symonds, A., Hunt, S.C., 1996. The midwife and the society: perspectives, policies and practice. Palgrave Macmillan, New York.

The guardian, 2015. All nurses to have degrees from 2013. http://www.theguardian.com/society/2009/nov/12/nurses-nursing-qualifications-degrees-nmc$\underline{\operatorname{rcn}}(27.5 .2015)$

Tierney, A., 1997. The development of nursing research in Europe. European nurse 2, 73-84. 
Mivšek P, Pahor M, Hlebec V, Hundley V (2015) How do midwives in Slovenia view their professional status? Midwifery (early online) http://www.sciencedirect.com/science/article/pii/S0266613815002260

Treacy, M., Hyde, A., 1999. Contextualising Irish nursing research. In: Nursing research, design and practice. University college Dublin press, Dublin. pp. 3-15.

Turner, B.S., 1995. Medical power and social knowledge. 2nd ed. SAGE Publications, London.

Van Lerberghe W, Matthews Z, Achadi E, et al., 2014. Country experience with strengthening of health systems and deployment of midwives in countries with high maternal mortality. Lancet 384(9949), pp. 1215-25.

WHO, 2006. Working together for health. The world health report 2006. World Health Organization, Geneva.

Witz, A., 1992. Professions and patriarchy. Routledge, London. 